\title{
Świat islamu w relacjach biograficznych - panorama problematyki (aspekty edukacyjne)
}

\section{The World of Islam in Biographical Relations - Panorama of Problems (Educational Aspects)}

\begin{abstract}
The article presents a panorama of biographical works, drawing pictures of life in Muslim communities. The stories were built by authors around several fundamental themes: conflicts in mixed marriages, experiences of specific violence in the Muslim family, persecution of dissenters, terror in the dominions under the rule of i.e. ISIS, Boko Haram, a terrorism and Islamic fanaticism danger. In addition, a large group of diaries take as a main theme the reform of Islam and conversions from Islam to Christianity. The image of the Islamic world that emerges from the diaries is a reality where violence motivated religiously and culturally is a basic problem. So the experience of violence or opposition to it is the main plot of all narrations. Primarily, the authors point to sharia - the religious law of Islam - as the main source of violent behaviour.
\end{abstract}

Keywords: Islam, sharia, biography, religion, culture, education.

* Małgorzata Stopikowska (ORCID: 00oo-0001-8705-8296) - dr hab., prof. Ateneum Szkoły Wyższej w Gdańsku, kierownik Katedry Nauk o Rodzinie na Wydziale Studiów Edukacyjnych Ateneum, kontakt: malgorzata.stopikowska@gmail.com. 
Tajemniczy świat islamu ${ }^{1}$, a zwłaszcza jego haremy, przepych i egzotyka,
zawsze budził zainteresowanie wśród mieszkańców krajów europejskich.

1 Należy nadmienić, że współczesny świat islamu nie jest monolitem, a poza dwoma głównymi nurtami (sunnici i szyici) istnieje również wiele innych odłamów tej religii. Warto też wspomnieć o różnicach narodowych, językowych i kulturowych, odrębnościach historycznych, prawnych i organizacyjno-administracyjnych każdego kraju. Co więcej, w każdej społeczności muzułmańskiej rozumienie zobowiązań religijnych i ich przestrzeganie jest również zróżnicowane, a postawy społeczno-polityczne są rozpięte na szerokiej skali od liberalnych i umiarkowanych po ekstremistyczne.

Wszystkie jednak frakcje jednoznacznie odwołują się do objawienia koranicznego jako podstawowego źródła religijnego oraz do Sunny Proroka. Muzułmanie wierzą, że ziemski Koran, objawiony Mahometowi, jest jedynie ujawnieniem niebieskiej Księgi-Matki, która w niezawodny sposób poucza wiernych, jakie wymagania wobec ludzkości ma Allah. Jako tekst boski jest niezmienny, nienaruszalny i absolutnie wiarygodny, choć naukowcy do dzisiaj spierają się, ile było wersji tekstu Koranu, zanim ostatecznie skodyfikował go Usman - Trzeci Kalif Sprawiedliwy. Natomiast ze świetlanym przykładem życia Mahometa, najdoskonalszego wyznawcy Allaha, można zapoznać się poprzez Sunnę - zbiór opowieści na temat czynów i wypowiedzi proroka Mahometa, przekazanych w opowieściach (hadisach) przez przyjaciół, towarzyszy Proroka i świadków jego życia, zebranych dopiero po wielu latach, a nawet wiekach, od śmierci Mahometa. Sunnici uznają za autentyczne 6 zbiorów hadisów, a szyici - 4 inne.

Na podstawie Koranu i Sunny (a niekiedy także innych elementów) zostało wypracowanych pięć głównych szkół prawa islamskiego, czyli szariatu - cztery sunnickie i jedna szyicka. Prawo muzułmańskie kształtowało się głównie do X w., gdy bramy Idżtihadu (interpretacji) zostały zamknięte (w szyizmie interpretacja jest do pewnego stopnia stosowana nadal). Poszczególne szkoły przedstawiają do dzisiaj obowiązującą wykładnię prawa szariackiego, choć - ze względu na globalizację - bywa, że na danym terenie stosowane są rozwiązania różnych szkół - w zależności od tego, jakie zalecenie bardziej odpowiada danej wspólnocie (wszystkie szkoły zgadzają się ze sobą w sprawach zasadniczych, natomiast różnią się w kwestiach szczegółowych, np. czy obrzezanie kobiet jest zalecane, czy też nie). Szariat ma status Prawa Bożego, mającego absolutny prymat wobec wszelkich innych ludzkich kodeksów prawnych. We współczesnym świecie islamskim szariat jest stosowany w prawie państwowym, głównie w zakresie prawa rodzinnego, choć takie kraje jak Arabia Saudyjska czy Katar kierują się nim przy rozstrzyganiu wszystkich spraw.

Prawo zwyczajowe w poszczególnych krajach funkcjonuje obok szariatu, ale jest z nim kompatybilne, i - choć często sięga korzeniami do czasów przedislamskich to jednak jako niesprzeczne $\mathrm{z}$ islamem i odwołujące się do niego funkcjonuje nadal. Więcej na powyższe tematy np.: J. Danecki, Podstawowe wiadomości o islamie, Warszawa 2007; K. Kościelniak, Sunna, hadisy, tradycjoniści, Kraków 2006; M. Stopikowska, Różnice doktrynalne: islam i chrześcijaństwo - wybrane aspekty, (mps.); E. Khidayer, Arabski świat, przeł. A. Mickiewicz-Janiszewska, Warszawa 2012, s. 15-49). 
W ostatnich dziesięcioleciach romantyczne sentymenty nie były jednak jedyną przyczyną kierowania uwagi w stronę tego świata: nadal trudno zapomnieć o tragicznych wydarzeniach z 11 września 2001 r., wojnie w Afganistanie, Iraku czy Syrii lub też o aktach terroru dokonywanych w różnych miejscach globu. Coraz większa liczba imigrantów i uchodźców osiedlająca się na tzw. Zachodzie budziła i budzi nadal zaniepokojenie tym bardziej, że media stale donoszą o różnorakich problemach i zamachach przeprowadzonych bądź choćby planowanych przez osoby z tłem imigracyjnym.

Szczególną okazję do wglądu w ten świat stwarzają pamiętniki traktujące o różnorodnych aspektach życia muzułmanów. Na rynku czytelniczym można znaleźć setki pozycji książkowych, pochodzących spod pióra zarówno Polaków, jak i autorów zagranicznych - przedstawicieli Zachodu oraz Orientu. Wydaje się, że wspomniane utwory biograficzne są jednym z najłatwiej dostępnych i popularnych źródeł wiedzy o świecie islamu. Warto zatem prześledzić, jakie obrazy kreślą przed czytelnikiem poszczególni autorzy i co z tego faktu wynika pod względem edukacyjnym. Biografii wydanych w języku polskim jest rzeczywiście mnóstwo, zatem do poniższych analiz wybrałam te pozycje, które uznałam za najbardziej reprezentatywne dla danego tematu.

\section{„Mój mąż potwór" - małżeństwa mieszane i przemoc}

Pierwszą znaczącą biografią o tej tematyce była zapewne historia Betty Mahmoody, która po kilku latach małżeństwa znalazła się wraz z mężem i córką na wakacjach w ojczystym dla męża Iranie. Tam małżonek przeistoczył się w bezwzględnego „pana i władcę”, a żona została wraz z córką uwięziona w jego domu rodzinnym w Teheranie. Dopiero po wielu perypetiach udało im się umknąć ${ }^{2}$. Na podstawie opisanych wydarzeń nakręcono film ${ }^{3}$, a książka stała się bestsellerem. Podobnych historii jest o wiele więcej i, niestety, bohaterkami części z nich są także Polki ${ }^{4}$.

2 B. Mahmoody, Tylko razem z córką, przeł. M. Kwiatkowska, Warszawa 1992.

3 Film: Not Without My Daughter, https://www.youtube.com/watch?v=oTsmbayujco, dostęp: 15.05.2019.

4 Np. I. Falaise, Mój mąż potwór, przeł. A. Sauvignon, Warszawa 2016; J. Trevane, Fatwa. Życie w nieustannym zagrożeniu, przeł. H. Pawlikowska-Gannon, Frydek-Mistek 2006; A. Brahimi, W niewoli algierskiego prawa, Wrocław 1999; N. Hamid, Gorzka pomarańcza, Pelplin 2016. 
$\mathrm{Na}$ tle zarysowanych powyżej problemów w małżeństwach mieszanych, ciekawie jawi się autobiograficzna opowieść Sylwii Kaźmierczak-Ali5 , która wskazuje postawy nadmiernej uległości kobiet wobec mężczyzn, sięgające aż do wyparcia się samej siebie, jako jedną z przyczyn niepowodzeń w związkach wielokulturowych. Autorka jest wprawdzie dopiero kilka lat w małżeństwie mieszanym, trudno zatem przewidzieć, w jakim kierunku ów związek się rozwinie, jednak jej przemyślenia nt. perturbacji w tego typu relacji oraz potrzebie zachowania tożsamości i niezależności oceniam jako cenne.

Historie dzieci z małżeństw mieszanych bywają również niekiedy tak dramatyczne jak losy kobiet wchodzących w małżeństwa mieszane. Głównym zagrożeniem jest porwanie dzieci przez ojca i wywiezienie do jego ojczyzny. Tego typu działanie ma zazwyczaj podwójny cel: zemsta na nieposłusznej żonie oraz odcięcie dziecka od wpływów zachodniej kultury, by wychować je na przykładnych muzułmanów. Nie chodzi przy tym o dobro dziecka, ale o motywy egoistyczne: delektowanie się posiadaniem i egzekwowaniem władzy, a nierzadko także przyjemność zadawania bólu zależnym od siebie osobom ${ }^{6}$.

Trzeba przyznać, że rodzicielskie uprowadzenia są zjawiskiem występującym niezależnie od kontekstu kulturowego ${ }^{7}$. Jednak w kulturze zbudowanej na islamie występuje legitymizacja religijna tego typu postępków. Zgodnie z szariatem dzieci "należą" do ojca i jego rodziny - w sytuacji rozwodu mogą pozostać z matką-muzułmanką tylko podczas pierwszych lat życia, a w przypadku śmierci ojca - prawo do opieki nad małoletnimi przechodzi na jego rodzinę. Wdowa może zatrzymać dzieci jedynie w przypadku, gdy jest muzułmanką i nie wyjdzie ponownie za mąż. Niemuzułmanka jest pozbawiona jakichkolwiek praw do majątku i wychowywania wspólnych dzieci ${ }^{8}$.

5 S. Kaźmierczak-Ali, Wybuchowe związki: mał̇̇enstwo z Pakistańczykiem, Gdynia 2019.

6 N. Hamid, Dzieci szariatu: losy tych, o których upomniał się islam, Pelplin 2018, S. $33-155$.

7 D. Dajnowicz-Piesiecka, Porwania rodzicielskie $w$ świetle polskiego orzecznictwa karnego $w$ ujęciu prawnym i kryminologicznym (na podstawie badań aktowych), „Dziecko Krzywdzone. Teoria, badania, praktyka”, 15 (2016) nr 4, s. 74-79.

8 M. Zyzik, Małżeństwo w prawie muzułmańskim, Warszawa 2003, s. 28-177; T. Białobrzeski, Małżeństwo katolika z muzułmaninem $w$ świetle Instrukcji Konferencji Episkopatu Hiszpanii z 2008 roku, „Ius Matrimoniale”, 22 (2011) nr 16, s. 122-126; 
Najbardziej reprezentatywną pozycją dotyczącą porwań dzieci w związkach mieszanych jest niewątpliwie autobiografia Donyi Al-Nahi - brytyjskiej konwertytki na islam oraz ekspertki od uprowadzeń rodzicielskich. Jak pisze, „pragnę podkreślić, że [...] jeżeli uprowadzenie dzieci mogło dotknąć mnie osobę zajmującą się dziesiątkami tego typu spraw, która doskonale wiedziała, na jakie sygnały zwracać uwagę, by mieć się na baczności - z pewnością może to spotkać każdą matkę w mieszanym małżeństwie" gorzka refleksja, że na obwolucie jej poprzedniej książki widnieje informacja: „Szczęśliwa żona Irakijczyka”.10.

O ile Al-Nahi i Mahmoody piszą przede wszystkim o uprowadzeniach zakończonych powrotem dzieci do matki, o tyle nie wszystkie historie mają szczęśliwy koniec. Dziewczynki mogą zostać wydane przymusowo za mąż a chłopcy - wcieleni do szkół koranicznych i przygotowani do dżihadu ${ }^{12}$. Prawo cywilne w państwach muzułmańskich jest zazwyczaj zgodne z szariatem, zatem rodzina i państwo będzie chroniło mężczyznę i jego prawa wobec potomków. Najczęściej jedyną szansą odzyskania dziecka jest zorganizowanie porwania, gdyż legalne środki są mało skuteczne ${ }^{13}$. Analizując powyższe historie, można zauważyć, że główną siłą niszczącą związek był wpływ szariatu na mentalność i zachowania muzułmańskiego męża i ojca ${ }^{14}$. Nie bez znaczenia był także fakt, że kobiety, wchodząc w związek, nie znały lub nie doceniały znaczenia uwarunkowań kulturowo-religijnych i ich wpływu na osobowość małżonka.

B. Prochwicz-Studnicka, M. Teperska-Klasińska, Cywilizacja islamu. Wybrane struktury, „The Polish Journal of the Arts and Culture”, 3 (2012) nr 3, s. 190-198.

9 D. Al-Nahi, Oddaj mi dzieci: dramatyczna opowieść o determinacji matki walczącej o odzyskanie porwanych dzieci, przeł. J. Pierzchała, Warszawa 2006, s. 7.

10 D. Al-Nahi, Bohaterka pustyni, przeł. A. Radkiewicz, Warszawa 2004.

11 Z. Muhsen, Sprzedane przez ojca, przeł. M. Rostworowska, Warszawa 2013, s. 59-72.

12 A. Khan, Islamski bękart, przeł. J. Skowroński, Warszawa 2013, s. 158-208; N. Hamid, Dzieci szariatu, s. 78-97.

13 D. Al-Nahi, Bohaterka pustyni, passim.

14 M. Stopikowska, „Przeżyłam piekło” - doświadczenia kobiet w świetle pamiętników muzułmanek i żon muzułmanów - między stereotypem a rzeczywistością, w: Etykieta czy drogowskaz? Rola stereotypów w przestrzeniach edukacyjnej różnorodności, red. M. Łojko, M. Grochalska, Olsztyn 2013, s. 203-220. 


\section{„Honor albo śmierć" - przemoc w muzułmańskiej rodzinie i społeczności}

Kolejną grupą wspomnień - pogłębiających i wyjaśniających nakreślony powyżej obraz - są pamiętniki muzułmanek, dające świadectwo doświadczonej przemocy w rodzinie. Autorki są zarówno mieszkankami krajów islamskich, jak i Europy oraz Ameryki - gdzie mieszkały od lat i pozornie żyły jak pozostałe obywatelki. Wiele z nich latami doznawało krzywd i dopiero ucieczka na Zachód lub wzbudzenie zainteresowania mediów ich sytuacją doprowadzily do zmiany ich położenia na lepsze ${ }^{15}$.

Przemoc domową dokumentuje np. Samia Shariff ${ }^{16}$. Dość podobna jest relacja Ouardy Saillo, której matka została zasztyletowana, związana, oblana benzyną i spalona. Pomimo że agresja męża stopniowo narastała, nikt - ani rodzina, ani sąsiedzi, ani policja - nie interweniował i nie przerwał szaleństwa przemocy ${ }^{17}$. Obrazy różnych aspektów sprawowania władzy przez mężczyzn i podległości im kobiet przedstawia z kolei Åsne Seierstad w bestsellerze Księgarz $z$ Kabulu ${ }^{18}$.

O wymuszonych małżeństwach pisze np. Francuzka marokańskiego pochodzenia - „Leila” ${ }^{\prime 19}$. Ofiarami wymuszonego małżeństwa były także siostry Muhsen (w wieku 14 i $16 \operatorname{lat}^{20}$ ), podobnie jak małoletnia Nadżud Ali ${ }^{21}$. Warto pamiętać, że wymuszone małżeństwo oznacza najczęściej także gwałt, gdy „małżonek” chce wyegzekwować swoje „prawo” do ciała żony ${ }^{22}$.

Niezwykle wstrząsająca jest lektura pracy Ayse Onal, która odtwarza biografie ofiar mordów honorowych, podpierając się wywiadami z ich spraw-

15 Tamże, s. 203-220.

16 S. Shariff, Za zasłona strachu, przeł. J. Józefowicz-Pacuła, Warszawa 2011; tejże, Pohańbione, przeł. J. Józefowicz-Pacuła, Warszawa 2011.

17 O. Saillo, Księżyc we łzach, przeł. B. Ostrowska, Warszawa 2010, s. 92-100.

18 A. Seierstad, Księgarz z Kabulu, przeł. A. Marciniakówna, Warszawa 2005.

19 Leila, Zmuszona do małżéstwa, przeł. B. Walicka, Warszawa 2018.

20 Z. Muhsen, Sprzedane przez ojca, s. 6o-61, 75, 81.

21 N. Ali, Dziesięcioletnia rozwódka, przeł. E. Wolańska, Warszawa 2009.

22 Np. S. Shariff, Za zasłona strachu, s. 78-80; Z. Muhsen, Sprzedane przez ojca, s. 70-72, 123; Leila, Zmuszona do małżeństwa, s. 202-204; N. Ali, Dziesięcioletnia rozwódka, s. $61-63$. 
cami ${ }^{23}$. Z perspektywy siostry ofiary pisze Nourig Apfeld - syryjska imigrantka w Niemczech. Jej siostra - uznana za nieposłuszną i zagrażającą honorowi rodziny - została najpierw uprowadzona z Niemiec, a potem przekazana rodzinie „na wychowanie”. Po ucieczce i powrocie do Niemiec została zamordowana przez ojca i kuzyna ${ }^{24}$. Natomiast punkt widzenia ofiary odsłania Palestynka ukrywająca się pod pseudonimem „Souad”. Rodzina wydała na nią wyrok: śmierć przez spalenie za pozamałżeński seks. Dziewczyna przeżyła wprawdzie atak, ale gdyby nie pomoc ze strony organizacji europejskiej, nie miałaby szans na przetrwanie ${ }^{25}$.

Nie mniej szokujące dla polskiego czytelnika wydają się wyroki sądowe za cudzołóstwo - takie jak w przypadku Nigeryjki Safiya Hussaini ${ }^{26}$. W prawie szariatu nielegalny seks obwarowany jest najsurowszymi karami ${ }^{27}$, dlatego też Hussaini została skazana na śmierć. Dopiero dzięki zainteresowaniu światowych mediów i wysiłkowi prawników działających na rzecz kobiet, została uwolniona od kary śmierci na podstawie casusu o „ciąży utajonej”28.

Sporo czasu w więzieniu spędziła także Touria Tiouli - ofiara zbiorowego gwałtu $^{29}$. Niezrozumiała dla Europejczyka sytuacja ukarania ofiary zamiast sprawcy gwałtu jest łatwa do wyjaśnienia w świetle szariatu. Koran uznaje za legalny tylko seks w małżeństwie i z niewolnicami. Aby zgwałcona kobieta mogła udowodnić swoją niewinność musi przedstawić świadków, chyba że sprawca sam złoży obciążające go zeznania. Inaczej kobieta staje się winna

23 A. Onal, Honor albo śmierć. Niewierne będa ginąć, przeł. J. Żuławnik, Warszawa 2009.

24 N. Apfeld, Widziałam, jak zamordowano moją siostrę, przeł. A. Zaniewska, Ożarów Mazowiecki 2015

25 Souad, Spalona żywcem, współpraca M. T. Cuny, przeł. M. Rostworowska, Warszawa 2004.

26 S. Hussaini, Żyję dzięki wam, przeł. M. Żbikowska, Warszawa 2004.

27 K. Sadowa, Przewinienia hudūd $w$ klasycznym prawie karnym muzułmańskim zarys tematyki, „Acta Erasmiana”, 15 (2017) S. 36-37.

28 Od wymierzenia kary za popełnienie hudūd nie może uwolnić żadna instancja ludzka (tamże, s. 31-32), zatem jedyną szansą uwolnienia Safii było udowodnienie, że córka jest dzieckiem jej byłego męża; A. Ibrahim, [Opinia prawna w sprawie Safiyi Hussaini], w: S. Hussaini, Żyję dzięki wam, s. 152).

29 Tiouli T., Honor kobiety. Ofiara gwałtu uwięziona w Dubaju, przeł. M. Kowalska, Warszawa 2007. 
i cudzołóstwa, i bezpodstawnego oskarżenia sprawcy ${ }^{30}$. Wniosek nasuwa się sam: lepiej w ogóle nie zgłaszać przestępstwa, a najlepiej - nikomu nic nie mówić, gdyż bez znaczenia jest to, czy nielegalny seks odbył się za zgodą kobiety, czy też wbrew.

Obsesja na punkcie kontrolowania seksualności kobiet miewa także inne odsłony: wycięcie żeńskich genitaliów (FGM), czyli tzw. obrzezanie. Najbardziej znaną działaczką zaangażowaną w walkę z tym procederem jest Waris Dirie autorka serii książek poświęconych temu zagadnieniu. O swoich losach pisze $\mathrm{m}$. in. w książce Kwiat pustyni ${ }^{31}$. Należy uznać, że influencja islamu jest jednym z ważniejszych faktorów występowania FGM: 9 na 10 krajów, w których przynajmniej 75\% kobiet przeszło FGM, to kraje ze zdecydowaną większością muzułmańską ${ }^{32}$. Trzeba jednak podkreślić, że tylko część szkół prawa muzułmańskiego zaleca, choć nie nakazuje, mutylację kobiet, odnosząc ją przez analogię do obligatoryjnego obrzezania mężczyzn ${ }^{33}$.

Czy opisywane przypadki ekstremalnej przemocy są jedynie wybrykami poszczególnych osób, czy mają jakąś inspirację w prawie islamu? Trudno w kilku słowach omówić tak skomplikowane zagadnienie, ale warto wskazać przynajmniej kilka ważniejszych elementów składających się na religijny kontekst dla tych specyficznych form przemocy wobec kobiet ${ }^{34}$. Koran ustanawia wyższość społeczno-prawną mężczyzny i jemu przyznaje opiekę nad kobietą wraz z związanymi z tym

30 Koran nakazuje, aby cudzołożnik żenił się/wychodził za mąż tylko za cudzołożnika. Stąd łatwo o wniosek, że najlepiej, aby gwałciciel ożenił się z ofiarą, dzięki czemu unika się perturbacji społeczno-prawnych. Szerzej o problemie: K. Kościelniak, Wszeteczeństwo, w: tejże, Tematyczna konkordancja do Koranu, Kraków 2006, s. 400; K. Sadowa, Przewinienia hudūd, s. 36, 38; taż, „Zbrodnie „honorowe” problemem współczesnej Europy? Zarys tematyki, „Wrocławskie Studia Erazmiańskie”, 7 (2013) s. 217-219.

31 W. Dirie, C. Miller, Kwiat pustyni, przeł. M. Wrześniewski, Warszawa 1999.

32 Female genital mutilation (FGM) data, https:/data.unicef.org/resources/dataset/ fgm/, dostęp: 06.06.2019.

33 Mówią o tym islamskie źródła, powołując się na Sunnę, np.: Is there any saheeh hadeeth about the circumcision of females?, https://islamqa.info/en/answers/82859/ is-there-any-saheeh-hadeeth-about-the-circumcision-of-females, dostęp: 06.06.2019.

34 K. Sadowa, Zbrodnie „honorowe”, s. 215-216; A. Gutkowska, Kulturowa przemoc ze względu na płeć. Przypadek zabójstw honorowych, „Archiwum Kryminologii”, 35 (2013) s. 142-152. 
obowiązkami i prerogatywami, natomiast kobieta powinna być mu posłuszna ${ }^{35}$. Opiekun muzułmanki spełnia wobec niej zadania, które w prawie polskim są obowiązkiem opiekuna osoby ubezwłasnowolnionej ${ }^{36}$. Ponadto nakłada się na to obowiązek „opiekuńczej/usprawiedliwionej zazdrości” wobec kobiety ${ }^{37}$.

Nie bez znaczenia jest idea grzechów-przestępstw hudūd, które są bezpośrednim naruszeniem boskiego porządku prawno-społecznego, a ich ukaranie staje się obowiązkiem całej wspólnoty ${ }^{38}$. Natomiast nauczanie o wszeteczeństwie ma przełożenie na ukształtowanie muzułmańskiej koncepcji czystości, w której to kobieta przez odpowiedni strój i zachowanie - jest odpowiedzialna nie tylko za strzeżenie swojej cnoty, ale także za moralne prowadzenie się mężczyzn ${ }^{39}$. Kolektywne rozumienie honoru nakłada też kolektywny obowiązek chronienia czci kobiety, a jednostka, która przynosi wstyd rodzinie, hańbi każdego z członków rodu i w oczach społeczności każdy z rodu staje się „infamisem”. Nie dziwi zatem, że cała rodzina jest zazwyczaj zaangażowana w utrzymanie lub restytucję honoru ${ }^{40}$.

35 K. Kościelniak, Kobiety, w: Tematyczna konkordancja do Koranu, s. 148-154; Islam. Sto pytań. odpowiada Samir Khalil Samir, Warszawa 2004, s. 69.

36 M. Sitek, Opieka i kuratela dotycząca osoby ubezwłasnowolnionej w prawie polskim, „Internetowy Przegląd Prawniczy TBSP UJ”, 2013, nr 1 (11), s. 77-91; M. Dziekan, Dzieje kultury arabskiej, Warszawa 2008, s. 144; Perpetual Minors. Human Rights Abuses Stemming from Male Guardianship and Sex Segregation in Saudi Arabia, New York 2008, s. 7-33; M. Zyzik, Małżeństwo w prawie muzułmańskim, s. 36-41, 105-110.

37 „[...] jest rodzajem specyficznej zazdrości przypisywanej mężczyznom w ramach autorytetu, jaki posiadają w stosunku do podległych im krewnych, w szczególności kobiet” (K. Sadowa, Zbrodnie „honorowe”, s. 191). Owa „zazdrość" ukierunkowana jest nie tylko na zachowanie samego honoru jako takiego, ale na ochronę muzułmańskiej moralności i rozciąga się na kontrolę kobiecej seksualności wraz z jej atrybutami (tamże; zob. też: taż, Ghayra i namus a zjawisko zbrodni "honorowych" w społecznościach muzułmańskich - zarys problemu, „Wrocławskie Studia Erazmiańskie”, 9 (2015) s. 382-390). Nie dziwi zatem, że muzułmańscy uczeni podkreślają, że poskromienie seksualności kobiet jest podstawową korzyścią praktyki FGM (np. Medical benefits of female circumcision, https://islamqa.info/en/answers/45528/medical-benefits-of-female-circumcision, dostęp: 01.06.2019.

38 K. Sadowa, Przewinienia hudūd, s. 31-32.

39 Taż, Zjawisko tzw. zbrodni honorowych $w$ Europie a koncepcja czystości $w$ islamie zarys problematyki, „Colloquium Wydziału Nauk Humanistycznych i Społecznych AMW", 3 (2015) s. 186-191.

40 Tamże, s. 185-186; A. Gutkowska, Kulturowa przemoc ze względu na płeć, s. 142-152. 
Być może niektórzy mogliby sądzić, że przedstawione powyżej przejawy mizoginii wobec kobiet, to jedynie problemy zacofanych i biednych środowisk, niezdarzające się wśród osób wykształconych i „na poziomie”. Jednakże kultura zbudowana na fundamencie islamu wypływa z tych samych źródeł i „tu”, i „tam”.

\section{Mój pan i władca - muzułmański „high life”}

Historią swojej romantycznej miłości, która przerodziła się w dramat upokorzeń, zdrad i bicia podzieliła się m.in. Jacqueline Pascarl - Australijka, która zdecydowała się wyjść za malezyjskiego księcia ${ }^{41}$. Podobny przebieg miała historia Amerykanki Barbary Mosallai Bell - żony perskiego księcia, a w istocie jego niewolnicy ${ }^{42}$. O życiu towarzyskiej śmietanki w Pakistanie opowiada z kolei Tehmina Durrani - żona znanego polityka. Małżeństwo bardzo szybko przerodziło się w tragiczny ciąg upokorzeń, znęcania się, licznych zdrad ukochanego i intryg ${ }^{43}$.

Sekrety saudyjskich pałaców i świat muzułmańskich księżniczek zamkniętych w „złotych klatkach” odkrywa natomiast przed czytelnikami Sułtana ${ }^{44}$. $\mathrm{Na}$ ograniczenia natomiast nie narzekają zbytnio młodzi szejkowie, o ile narkotyki, alkohol i wyuzdane orgie są utrzymywane w tajemnicy ${ }^{45}$. Opisany we wspomnieniach świat - choć luksusowy, to jednak oparty jest na przedmiotowym traktowaniu kobiety, hipokryzji, rozlicznych intrygach i szaleństwach niepotrzebnych zakupów, mających wypełnić pustkę istnienia ${ }^{46}$. O ile prawowite małżonki mogą liczyć na pozory zachowywania wobec nich szacunku, to takiego przywileju nie mają już kochanice. Na ten obszar życia książęcych

41 J. Pascarl, Kiedyś byłam księżna, przeł. E. Szyler, Warszawa 2012.

42 B. M. Mosallai Bell, S. Harris, Perska księżniczka. Amerykanka z urodzenia, Iranka z miłości - prawdziwa historia jej życia, przeł. A. Cioch, Warszawa 1999.

43 T. Durrani, Mój pan i władca, współpraca M. M. i W. Hoffer, przeł. L. Simbierowicz, Warszawa 2012.

44 J. P. Sasson, Księżniczka, przeł. I. Chodorowska, Warszawa 2004.

45 M. Margielewski (Jak podrywają szejkowie, Warszawa 2019) opowiada o hulaszczym życiu emirackich szejków.

46 J. A. Larson, Woziłam arabskie księżniczki: opowieść szoferki o najbogatszych księżniczkach świata (oraz ich służących, nianiach i jednym królewskim fryzjerze), przeł. D. Malina, Kraków 2014, passim. 
rodów rzuca światło m.in. Jillian Lauren - Amerykanka, która była faworytą brunejskiego księcia ${ }^{47}$.

Dysponujemy także wspomnieniami byłych żon bajecznie bogatych braci Bin Laden: Szwajcarki Carmen oraz Syryjki Nadżwy - żony osławionego terrorysty. O ile początkowo małżeństwo Carmen układało się dobrze, to jednak z biegiem czasu tradycyjne saudyjskie zasady wzięły w nim górę, co doprowadziło do rozpadu małżeństwa ${ }^{48}$. Z kolei Nadżwa podjęła się innej drogi życia: dla Osamy i islamu zrezygnowała ze wszystkiego. Źródłem tej postawy była jej radykalizacja religijna uzasadniająca konieczność poddania się absolutnej władzy męża. Z pełnym przekonaniem stosowała się do najbardziej absurdalnych rozporządzeń Osamy ${ }^{49}$. O stopniu jej wewnętrznego zniewolenia świadczy fakt, że uważała się za szczęśliwą, a poczucia spełnienia nie burzyło nawet patrzenie na cierpienie własnych dzieci ${ }^{50}$.

\section{„Kalifat terroru” - dżihad dla Allaha}

Dla człowieka Zachodu zazwyczaj trudne jest powiązanie zagrożenia terrorystycznego z pieczołowitym wykonywaniem praktyk religijnych. Fenomenu przemocy podejmowanej w imię Allaha nie da się zrozumieć bez sięgnięcia do źródeł islamu ${ }^{51}$. Historia pierwotnej wspólnoty muzułmańskiej to zapis napadów rabunkowych, ludobójstwa, wojen zaczepnych i skrytobójczych morderstw, którym towarzyszyła religijnie podbudowania ideologia ${ }^{52}$. Ponadto problem w tym, że islam nie oddziela sacrum od profanum, regulując życie indywidualne i zbiorowe w każdym aspekcie - od sposobu podcierania się w toalecie przez ubiór i savoir vivre po kwestie polityczno-państwowe. Zatem

47 J. Lauren, Moje życie w haremie, przeł. E. Piotrowska, Warszawa 2012.

48 C. Bin Ladin, Rozdarty czarczaf: moje życie w Arabii Saudyjskiej, Katowice 2004.

49 Tamże, s. 97-99; J. Sasson, N. Bin Laden, O. Bin Laden, Musiałam odejść: wspomnienia żony i syna Osamy Bin Ladena, przeł. A. Sokołowska-Ostapko, Kraków 2012, s. 37, 73, 81-90.

50 J. Sasson, N. Bin Laden, O. Bin Laden, Musiałam odejść, s. 78-79, 97-98-101, 380-382.

51 M. Stopikowska, Różnice doktrynalne.

52 Tejże, Koran pod pachą imigranta - potencjalne zagrożenie?, w: Migracja: szansa czy zagrożenie?, red. J. Zimny, Stalowa Wola 2015, s. 173-201; M. Sadowski, Islam. Religia i prawo, Warszawa 2017, s. 83-93. 
im pobożniejszy muzułmanin, tym skrupulatniej chce wypełniać nakazy swojej religii - nie tylko dotyczące higieny, ubioru i modlitw, ale także w zakresie uporządkowania przestrzeni społeczno-politycznej ${ }^{53}$.

Dlatego też samo radykalne podejście do „neutralnych" obowiązków religijnych może być pierwszym sygnałem informującym o zamiarze realizowania islamu także na "niebezpiecznych" płaszczyznach. Przejście od jednego do drugiego bywa płynne, zwłaszcza że ciągle trwa intensywna akcja agitacyjna radykałów. O skuteczności tej propagandy mieli okazję przekonać się m.in. Sophie Kasiki $^{54}$, Melody ${ }^{55}$, Anna Sundberg ${ }^{56}$ czy Morten Storm ${ }^{57}$. Są to dość rzadkie świadectwa, dające wgląd w to, jak bardzo współczesna Europa jest przesiąknięta propagandą islamistyczną i siatką różnorodnych organizacji terrorystycznych ${ }^{58}$.

Kasiki, konwertytka zafascynowana opowieściami o idealnym Państwie Islamskim, porzuciła męża i wywiozła swoje dziecko na terytoria ISIs. Wprawdzie na miejscu „ochłonęła”, ale było już za późno, by wrócić do poprzedniego życia ${ }^{59}$. Melody - młoda Francuzka, uwiedziona przez bojownika ISIS (a raczej dziennikarka śledcza, która wcieliła się w rolę naiwnej dziewczyny) - bez przeszkód opuściła Francję, licząc na szczęście u boku dżihadysty ${ }^{60}$. Zresztą kandydatek na żony dla islamistów nie brakuje w Europie ${ }^{61}$.

53 M. Stopikowska, Muzułmanie i ich emigracja na „Zachód”, w: Migracja: szansa czy zagrożenie?, s. 25-50.

54 S. Kasiki, P. Guéna, Piekło ISIS, przeł. T. Markowski, Warszawa 2016.

55 A. Erelle, Dżihadystka: relacja z wnętrza komórki rekrutacyjnej Państwa Islamskiego, przeł. M. Chojnacki, Katowice 2015.

56 A. Sundberg, J. Huor, Żona terrorysty. Szesnaście lat życia wśród dżihadystów, przeł. I. Sawicka, Warszawa 2017.

57 M. Storm, P. Cruickshank, T. Lister, Agent Storm: we wnętrzu Al-Kaidy i CIA, Wołowiec 2013.

58 S. Laurent, Kalifat terroru. Kulisy działania Państwa Islamskiego, przeł. E. Kaniowska, Warszawa 2015, s. 13-22, 155-167; M. Orzechowski, Mój sąsiad islamista, Warszawa 2016, s. 79-282; M. Storm, P. Cruickshank, T. Lister, Agent Storm, s. 473-474; A. Sundberg, J. Huor, Żona terrorysty, s. 248-268; S. Kasiki, P. Guéna, Piekło ISIS, S. $46-74$.

59 S. Kasiki, P. Guéna, Piekło ISIS, s. 59-236.

6o Prowadzona przez Annę Erelle gra - śledzona przez francuski wywiad - doprowadziła do unieszkodliwienia kilku terrorystów (A. Erelle, Dżihadystka, s. 259-268).

61 M. Suc, Żony dżihadystów, przeł. K. Szeżyńska-Maćkowiak, Warszawa 2017. 
Podobną opowieść snuje Szwedka Sundberg: dla ukochanego przeszła na islam, a gdy jej mąż okazał się brutalem, rozwiodła się i powtórnie wyszła za mąż za innego salafitę - terrorystę Saida Arifa ${ }^{62}$. Towarzyszyła mu w jego wyprawach po Europie i na Wschód, dzieląc z nim gorliwość religijną i wynikające z niej poglądy. Dopiero po uwięzieniu męża, odseparowana od niego, zdobyła się na refleksję nad swoim życiem, podjęła niegdyś przerwaną edukację, co ostatecznie doprowadziło do odrzucenia islamu oraz decyzji o rozwodzie ${ }^{63}$.

Z kolei Storm po wyjściu z więzienia zainspirował się życiorysem Mahometa i przeszedł na islam ${ }^{64}$, a następnie wyjechał do Jemenu do szkoły koranicznej, gdzie przystąpił do ugrupowań terrorystycznych ${ }^{65}$. Chociaż z oddaniem zaangażował się w prace na rzecz światowego dżihadu (s. 48-177), to jednak porzucił islam po zauważeniu sprzeczności w Koranie i braku logicznej spójności wyznawanej wiary (s. 178-182). Następnie zgłosił się na ochotnika jako informator wywiadu duńskiego, angielskiego i amerykańskiego, aby zapobiegać aktom terroryzmu.

O terrorze panującym w islamskich dominiach piszą m.in. Marcin Mamoń dziennikarz uprowadzony w Syrii przez Al-Kaidę ${ }^{66}$, Syryjczyk „Samir" ${ }^{\text {67 }}$, dziennikarka Marhjon van Dalen, która zebrała wspomnienia byłych terrorystów z Boko Haram ${ }^{68}$. Ważną perspektywę rysują także: działaczka afgańskiego ruchu oporu "Zoja”69 czy pakistańska policjantka Jamila Barakzai - ukazujące ucisk wobec kobiet, ale też i ich opór stawiany prześladowcom ${ }^{70}$.

Polski czytelnik, który poszukiwałby literatury traktującej o pracy szpiegów i żołnierzach walczących z hydrą światowego terroryzmu, też znajdzie dla siebie kilka ciekawych pozycji. Typowo wojenne biografie niewiele jednak rzucą światła na sam dżihad - ukazują raczej odwagę, braterstwo broni i patriotyczny

62 A. Sundberg, J. Huor, Żona terrorysty, s. 39-82.

63 Tamże, s. 230-295.

64 M. Storm, P. Cruickshank, T. Lister, Agent Storm, s. 48-63.

65 Tamże, s. 64-88.

66 M. Mamoń, Wojna braci. Bojownicy, dżihadyści, kidnaperzy, rozm. A. Drożdżak, Kraków 2017.

67 Samir, Zapiski z Rakki. Ucieczka z Państwa Islamskiego, przeł. M. Romanek, Kraków 2017.

68 M. van Dalen (Kalifat albo śmierć, przeł. K. Markiewicz, Poznań 2017.

69 Zoja, Wszystkie jesteście niewierne. Piekło kobiet w Afganistanie, Warszawa 2009.

70 J. Barakzai, Pod burka, przeł. H. Abramowicz, Warszawa 2011. 
wysiłek żołnierzy. Wspomniane książki są swoistym hołdem dla tych, którzy poświęcili swoje życie i bezpieczeństwo, aby chronić nasz świat ${ }^{71}$. Natomiast wgląd w umysł terrorysty i w pracę służb specjalnych możemy uzyskać dzięki wspomnieniom Storma, który przyczynił się do eliminacji groźnych dżihadystów, w tym Anwara Al-Awlakiego ${ }^{72}$, oraz bezimiennej amerykańskiej agentki, która śledziła zwolenników dżihadu w USA ${ }^{73}$.

\section{„Prześladowani za wiarę" - dramatyczny los chrześcijan i jazydów}

Na trudny los chrześcijan pod panowaniem muzułmanów wskazują liczne pamiętniki dotyczące zarówno wydarzeń historycznych, jak i współczesnych. O nadal mało znanym ludobójstwie Ormian dokonanym przez osmańskich Turków opowiada np. Abed z Karabasz ${ }^{74}$. Współczesnym symbolem prześladowań są natomiast dwie chrześcijanki: Pakistanka Asia Bibi - skazana na śmierć za plotkę o zniesławieniu przez nią Mahometa ${ }^{75}$ oraz Sudanka Meriam Ishag - oskarżona o konwersję na chrześcijaństwo ${ }^{76}$. Ich losy ukazują, jaka siłę posiada przywiązanie muzułmańskich społeczności do szariatu, karzącego śmiercią apostatów i bluźnierców ${ }^{77}$.

Z danych fundacji Open Doors wynika, że obecnie na 50 krajów prześladujących chrześcijan w $40 \mathrm{z}$ nich podstawową przyczyną prześladowań jest ekstre-

71 Są to np. biografie żołnierek biorących udział w akcjach w Afganistanie (G. T. Lemmon, Wojna Ashley, przeł. J. Ochab, Warszawa 2017), wspomnienia angielskiego ochotnika walczącego z ISIS (E. Nash, Pustynny snajper, przeł. R. Kot, Poznań 2019) oraz komandosa, który brał udział w operacji Trójząb Neptuna (M. Owen, Niełatwy dzień, autobiografia komandosa Navy SEAL: pierwsza i jedyna relacja komandosa sił specjalnych Navy SEAL, które doprowadziły do śmierci Osamy Bin Ladena, przeł. Ł. Małecki, Kraków 2013).

72 M. Storm, P. Cruickshank, T. Lister, Agent Storm, s. 360-392.

73 N. N., Polowałam na terrorystów, przeł. M. Szubert, Warszawa 2004.

74 Abed z Karabasz, Seyfo - ludobójstwo, o którym nie wolno mówić. Dziennik seminarzysty o ludobójstwie Ormian i Asyryjczyków w roku 1895 i w latach I wojny światowej, Poznań 2015.

75 A. Bibi, A. I. Tollet, Bluźnierstwo, przeł. P. Bachtin, Warszawa 2012, s. 34-58.

76 A. Napoli, Mam na imię Meriam. Historia chrześcijanki skazanej na śmierć w obronie wiary, przeł. K. Dyjas-Fezzi, Kraków 2016, s. 53-56.

77 K. Sadowa, Przewinienia hudūd, s. 40-41; D. Wąsik, Bluźnierstwo w wybranych kulturach prawnych, „Studia Iuridica Toruniensia”, 15 (2014) s. 216-220. 
mizm islamski ${ }^{78}$. Warto pamiętać, że Koran jasno i wprost nawołuje do prześladowań innowierców aż do momentu zaprowadzenia na całym świecie islamu ${ }^{79}$. O uwięzieniach chrześcijan, gwałtach, przymusowych nawróceniach, porwaniach, morderstwach, pobiciach, grabieży i zniszczeniach mienia oraz o życiu w stałym zagrożeniu piszą zarówno rodzimi chrześcijanie z poszczególnych krajów, jak i konwertyci z islamu na chrześcijaństwo ${ }^{80}$. Najbardziej reprezentatywną dla tematu pozycją jest książka Brata Andrew i Ala Janssena ${ }^{81}$.

Szczególną grupę świadectw stanowią wyznania kobiet - dawnych niewol-

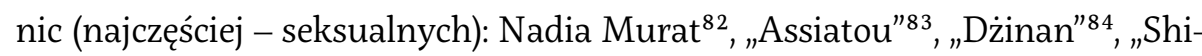
rin" $^{\prime \prime 5}$ oraz Farida Khalaf ${ }^{86}$. Autorki dzielą się swoim doświadczeniem gehenny w kalifacie, gdy zostały porwane i sprzedane, stając się ofiarami różnorodnego bestialstwa. Należy pamiętać, że zasady dot. niewolnictwa, w tym seksualnego, są częścią szariatu. Chociaż państwa muzułmańskie formalnie zniosły

78 Portal Open Doors, Prześladowania chrześcijan na świecie [wraz podlinkowaniami], https://www.opendoors.pl/przesladowania-chrzescijan/przesladowania-mapa, dostęp: 15.05.2019.

79 K. Kościelniak, Uzasadnienie przemocy, w: Tematyczna konkordancja do Koranu, s. 366-368; M. Sadowski, Islam, s. 135 i nast.

80 Marhjon van Dalen (Kalifat albo śmierć) opowiada historie lokalnych wspólnot chrześcijańskich w Nigerii prześladowanych przez Boko Haram; Daniel Gerber (Pozostały mi tylko łzy i modlitwa, przeł. K. Markiewicz, Poznań 2013) opisuje losy porwanych chrześcijanek pakistańskich i bezradność ich rodzin; Maryam Rostampour i Marziyeh Amirizadeh (Więźniowie Iranu: prawdziwa historia dwóch chrześcijanek, przeł. M. Rucki, Poznań 2013) dzielą się wspomnieniami z prowadzenia przez siebie misji chrześcijańskich i późniejszego uwięzienia.

81 Andrew, A .Janssen, Prześladowani za wiarę: dramatyczne historie chrześcijan nawróconych $z$ islamu, przeł. M. Wilk-Dziuba, Warszawa 2011.

82 N. Murat, J. Krajeski, Ostatnia dziewczyna: o mojej niewoli i walce z Państwem Islamskim, przeł. M. Koziej, Warszawa 2018.

83 Assiatou, M. Kaci, Uprowadzona przez Boko Haram, przeł. K. Szeżyńska-Maćkowiak, Warszawa 2018.

84 Dżinan, Oberle T., Niewolnica IsIs, współpraca Thierry Oberlé, przeł. N. Jaskula, Gliwice 2016.

85 Shirin, Cavelius A., Kizilhan J., Pozostanę córką światła. Moja ucieczka z rąk terrorystów, przeł. M. Jatowska, Warszawa 2017.

86 F. Khalaf, Dziewczyna, która pokonała IsIs. Moja historia, przeł. B. Tarnas, Warszawa 2016. 
niewolnictwo dopiero w XX w. (Mauretania kolejny raz w 2007 r.), to jednak jest ono praktykowane tam nadal ${ }^{87}$.

Wiele z porwanych kobiet nadal pozostaje w rękach bojowników Allaha, a tylko nielicznym udało się zbiec. Autorki wspomnianych biografii stanowią jednak wyjątkową grupę, a tytuły ich wspomnień wyrażają ich niezłomność ducha: Dziewczyna, która pokonała ISIs (F. Khalaf) czy Pozostanę córką światła („Shirin”). Zwycięstwem, które głoszą, jest fakt, że nie poddały się złu: przebaczyły oprawcom i nie pozwoliły, aby żądza zemsty i nienawiść zniszczyły w nich człowieczeństwo. Pragną, aby ich wyznania dały nadzieję innym skrzywdzonym kobietom i pokazały, że istnieje przed nimi przyszłość, że mają wewnętrzną siłę, aby zatryumfować nad zbrodniarzami.

\section{„Szukając Allaha znalazłem Jezusa” - konwersje z islamu na chrześcijaństwo}

Wbrew pozorom porzucenie islamu i zwrócenie ku Jezusowi Chrystusowi nie jest wcale takie rzadkie, jakby mogło się wydawać. Mimo niebezpieczeństw grożącym nawróconym, wielu z nich ryzykuje życie i woli nawet stracić wszystko, aby tylko pozyskać Chrystusa (Flp 3,7-8). Konwertyci pochodzą praktycznie ze wszystkich środowisk i nacji: od muzułmańskich magnatów po prostych robotników, od imamów i islamologów po analfabetów, od terrorystów i salafitów po „zwyczajnych” muzułmanów. Chrystusa wybierają zarówno kobiety, jak i mężczyźni - choć zgodnie z ich kulturą - to raczej mężczyźni są tymi, którzy prowadzą swoje żony i córki ku - jak mówią - „Pełni Prawdy”88.

87 K. Kościelniak, Niewolnicy, w: Tematyczna konkordancja do Koranu, s. 253; D. Oliwa, $W$ cieniu niewolnictwa - konfrontacja prawa $z$ rzeczywistościa $w$ systemie państwa i społeczeństwa Mauretanii, w: Prawa człowieka w kulturze północnej Afryki, Bliskiego Wschodu i Dalekiego Wschodu, red. K. Kościelniak, Kraków 2008, s. 69-87; Descent-based slavery, https://www.antislavery.org/slavery-today/descent-based-slavery/, dostęp: 01.06.2019.

Wspomnienia muzułmańskiej niewolnicy w Europie XXI w.: M. Nazer, D. Lewis, Niewolnica, przeł. H. Szajowska, Warszawa 2004.

88 R. Goode, Nikt ich nie zamknie: niezwykłe, prawdziwe historie Bożego działania w świecie islamu, przeł. D. Piotrowska, Warszawa 2011, s. 15-125; V. Morgan, Zaka- 
Szczególnie niezwykłą drogę od islamu do chrześcijaństwa odbyli: Joseph Fadelle $^{89}$, Ali Husnain ${ }^{90}$, Nabeel Qureshi ${ }^{11}$. Pochodząc z bogatych rodzin, szczycących się pochodzeniem od samego proroka Mahometa, posiadali wszystko, aby zająć należne im miejsce w muzułmańskiej społeczności. Próbując nawrócić na islam chrześcijan, podjęli się studiów własnej tradycji religijnej, a także dla porównania - Biblii. Z jednej strony dostrzegli niespójność tekstów Koranu i Sunny oraz ich mizerię intelektualną i moralną, a z drugiej - doświadczyli nadzwyczajnych wydarzeń, takich jak symboliczne sny i wizje, a w przypadku Ester - także cudowne uzdrowienie z paraliżu.

Świadectwo swojej intelektualnej drogi od islamu do Chrystusa dali także Mark A. Gabriel oraz Raszid Al-Maghribi. Obydwaj doszli do wniosku, że pełnia Prawdy została niezawodnie objawiona w Jezusie Chrystusie, a Koran i tradycja Mahometa zawierają nieusuwalne sprzeczności i wzywają do przemocy ${ }^{92}$.

Trochę w inny sposób dotarli do Chrystusa Tass Saada - snajper i bliski współpracownik Arafata oraz M. Jusuf - bojownik i syn jednego z założycieli Hamasu. Poznali chrześcijan i z nimi się zaprzyjaźnili, a po nawróceniu rozpoczęli działalność na rzecz pojednania między Palestyńczykami i Izraelczykami ${ }^{3}$. Przyjaźń z chrześcijanami oraz poszukiwanie prawdy doprowadziły do Chrystusa także Abdallę Hawatmeha, który został potem pastorem wspólnoty nawróconych z islamu w Jordanii ${ }^{94}$.

zana miłość, przeł. M. Leszczyk, Warszawa 2011, s. 274-326; S. James, Sabatina, Warszawa 2004, s. 171-194.

89 J. Fadelle, Bez względu na cenę, przeł. M. Cofta, Poznań 2011.

90 A. Husnain, J. Chester, Niewierny, przeł. A. Czwojdrak, Kraków 2016.

91 N. Qureshi, Szukając Allaha znalazłem Jezusa. Droga gorliwego muzułmanina do Chrystusa, przedm. L. Strobel, przeł. A. Dominowska, Ustroń 2015.

92 M. A. Gabriel, Jezus i Mahomet: głębokie różnice i zaskakujące podobieństwa, przeł. B. Grysa, Poznań 2013, s. 39-43, 285-291; R. Al-Maghribi, Czy Koran jest słowem Bożym? Świadectwo nawrócenia muzułmanina, przeł. S. Bednarowicz, Poznań 2011, S. 15-16, 239-240.

93 T. Saada, D. Merill, Byłem człowiekiem Arafata, przeł. M. Rucki, Poznań 2013; ciż, Umysł terrorysty: były snajper Arafata ujawnia motywy islamskich ekstremistów i podpowiada, jak przeciwdziałać terroryzmowi, przeł. A. Czwojdrak, Wrocław 2017; M. H. Jusuf, R. Brackin, Syn Hamasu, przeł. A. Kurzępa, Wrocław 2014.

94 R. Muller, Człowiek z Gadary, przeł. D. Piotrowska, Warszawa 2011. 


\section{„Mówisz, że chcesz rewolucji..."95 - o nowy kształt świata islamu}

W zasadzie każdemu z autorów wspomnianych powyżej relacji biograficznych przyświeca wspólny cel: przyczynić się choćby w jakimś stopniu do zmiany myślenia wyznawców islamu w kierunku akceptacji i przestrzegania praw człowieka oraz wprowadzenia zasadniczych reform religijnych. Pomysłodawcami zmian i krytykami islamu są sami muzułmanie lub apostaci. Do najbardziej znanych kontestatorów zasad islamu, należą m.in. Ayaan Hirsi Ali, Ibn Warraq, Nonie Darwish i Irshad Manji. Wspomniane osoby przelały swoje osobiste doświadczenia oraz opinie na karty obszernych opracowań o charakterze biograficzno-publicystycznym, a także biograficzno-naukowym ${ }^{96}$. Dla polskiego czytelnika ich książki mogą być świetnym źródłem do zapoznania się aktualnymi tendencjami reformistycznymi wewnątrz islamu - pod warunkiem jednak, że czytelnik ma już pewną wiedzę na jego temat.

I tak najważniejszym postulatem muzułmańskich dysydentów jest reinterpretacja Koranu i hadisów oparta na zasadzie krytyki źródeł i uwzględnienia ich historycznego kontekstu, tak aby odróżnić duchowe przesłanie od wezwań do przemocy i supremacji ${ }^{97}$. Odwołując się do dawnej i zarzuconej przed wiekami tradycji interpretowania wiary i jej źródeł, wzywają do ponownego otwarcia „bram idżtihadu"98 oraz do dostosowania islamu do osiągnięć cywilizacyjnych na polu praw człowieka oraz pokojowego współistnienia narodów i państw ${ }^{99}$.

95 Tak zatytułował jeden z rozdziałów M. Al-Samawi, Polowanie na lisy. Prawdziwa historia uciekiniera z Jemenu, przeł. M. Słysz, Warszawa 2019, s. 139.

96 A. Hirsi Ali, Niewierna. Grozili mi, że będę następna, przeł. J. Pierzchała, Warszawa 2009, tejże, Heretyczka, przeł. J. Żuławnik, Warszawa 2016; tejże, Nomadka. Zbuntowana przeciw islamowi, przeł. E. Krawczyk, Warszaw 2013; Ibn Warraq, Dlaczego nie jestem muzułmaninem, przeł. K. M. Wielgat, G. Kuśmierek, Warszawa 2013; N. Darwish, Okrucienstwo w majestacie prawa. Prześladowanie kobiet $w$ świecie islamu, przeł. L. Bigaj, Warszawa 2011; I. Manji, Kłopot z islamem, przeł. M. Świerkocki, Warszawa 2005.

97 A. Hirsi Ali, Heretyczka, 21-50; I. Manji, Kłopot z islamem, s. 174-188; P. I. Kalwas, J. Winiarski, Archipelag islam. Czas Koranu, czas zmiany: rozmowy bez cenzury, Nysa 2018, s. 195-227.

98 J. Danecki, Podstawowe wiadomości o islamie, s. 217-219; I. Manji, Kłopot $z$ islamem, S. 174-203.

99 I. Manji, Kłopot $z$ islamem, s. 174-203. 
Jednym z najważniejszych dezyderatów jest odrzucenie szariatu, a także wszelkich form ucisku i przemocy wobec kobiet wraz ze zmianą jakości relacji w rodzinie ${ }^{100}$. Reformatorzy wymieniają także inne postulaty: rezygnacja z ambicji światowej supremacji islamu i wprowadzenia jej za pomocą dżihadu $^{101}$, porzucenie nienawiści wobec żydów i innych innowierców ${ }^{102}$ oraz docenienie wartości życia doczesnego ${ }^{103}$. Nie mniej ważnym elementem sugerowanej reformy islamu miałoby być także odejście od ciasnego myślenia plemiennego, w którym pojedyncza osoba nie istnieje jako jednostka, a jedynie jako członek danego plemienia, klanu czy rodziny ${ }^{104}$. Niektórzy reformatorzy idą o wiele dalej: zachęcają do otwarcia się islamu także na mniejszości seksualne LGBTQ ${ }^{105}$.

Jednak pojawia się pytanie, czy postulowany przez reformatorów kształt islamu jest zgodny z Koranem i co więcej, czy odpowiadałby treściom zawartym w sunnie czy innych tradycjach. Krytykowane przez reformatorów idee są przecież integralną częścią świętych tekstów islamu, zatem podważenie tego typu przekazów jest jednocześnie zakwestionowaniem nienaruszalności objawienia Allaha ${ }^{106}$. Być może jest to przyczyna, dla której część dysydentów wobec tego typu nierozwiązywalnego dylematu odrzuca islam w całości, decydując się na apostazję i ateizm (np. Hirsi Ali, Ibn Warraq).

Inną drogę wyeliminowania przemocy z kultury muzułmańskiej proponują konwertyci z islamu na chrześcijaństwo, ale nie tylko oni. Wzywają mianowicie do głoszenia muzułmanom Chrystusa, widząc w Nim i Jego Ewangelii jedyne

100 Hirsi Ali, Heretyczka, s. 142-188; taż, Nomadka, s. 326-349; N. Darwish, Okrucieństwo $w$ majestacie prawa, s. 325-327.

101 Hirsi Ali, Heretyczka, s. 189-222.

102 M. Al-Samawi, Polowanie na lisy, s. 74-86; M. H. Jusuf, R. Brackin, Syn Hamasu, S. 129-141, 246-248, 261-269; T. Saada, D. Merill, Byłem człowiekiem Arafata, s. 229252; ciż, Umysł terrorysty, s. 211-248.

103 A. Hirsi Ali, Heretyczka, s. 121-141.

104 Ibn Warraq mówi wprost o arabskim imperializmie, a jednocześnie o kolonializmie kulturowym, korzystającym z uzasadnienia religijnego własnych podbojów (Dlaczego nie jestem muzutmaninem, s. 269-320).

105 I. Manji, Kłopot z islamem, s. 13-35; M. Al-Samawi, Polowanie na lisy, s. 113-119.

106 N. Darwish, Okrucieństwo w majestacie prawa, s. 27-28, 339-344; Ibn Warraq, Dlaczego nie jestem muzułmaninem, s. 65-221; A. Hirsi Ali, Heretyczka, s. 50-58. 
wyjście z niewoli szariatu ${ }^{107}$. Choć sama idea masowej ewangelizacji muzułmanów może się wydawać czystą fantasmagorią, to do podjęcia tego typu misji zachęcają także byli muzułmanie, którzy identyfikują siebie jako ateistów. Jest to dla nich utylitarnie uzasadniona idea: zamiast szukać religijnego fundamentu życia w dwuznacznym przesłaniu Koranu, lepiej poszukać go w Jezusowym jednoznacznym przesłaniu miłości ${ }^{108}$.

O ile konwersja wymagałaby radykalnego odcięcia się od islamu, o tyle poszerzenie dostępu do edukacji nie wymagałoby takich poświęceń. Jak wskazują wspomniani już autorzy, często już sama możliwość czerpania z alternatywnych źródeł wiedzy skłania do refleksji nad racjonalnością poszczególnych zasad religijnych ${ }^{109}$. Nic dziwnego zatem, że edukacja ucząca krytycznego myślenia może być traktowana jako zagrożenie dla radykalnie praktykowanej wiary, a takie osoby jak Malala - symbol walki o prawo muzułmańskich kobiet do edukacji i laureatka Pokojowej Nagrody Nobla w 2014 r. - stają się celem fanatyków $w^{110}$. Sytuacja nie jest jednak beznadziejna: to na zaproszenie lokalnej starszyzny w Pakistanie i Afganistanie G. Mortensen buduje tam kolejne szkoły - głównie dla dziewczą ${ }^{111}$. Można zatem powiedzieć, że część środowisk muzułmańskich aktywnie działa w kierunku skolaryzacji swoich społeczności, przeciwdziałając radykalizacji młodych pokoleń.

107 T. Saada, D. Merill, Umyst terrorysty, s. 165-188; A. Husnain, J. Chester, Niewierny, s. 340-346; M. A. Gabriel, Jezus i Mahomet, s. 291-295; R. Muller, Człowiek z Gadary, s. $84-86,318$.

108 A. Hirsi Ali, Nomadka, s. 350-374; N. Darwish, Okrucieństwo w majestacie prawa, s. 336-337.

109 M. Al-Samawi, Polowanie na lisy, s. 74-86; A. Hirsi Ali, Niewierna, s. 306-337; T. Saada, D. Merill, Umysł terrorysty, s. 211-246 M. H. Jusuf, R. Brackin, Syn Hamasu, S. 129-141; P. I. Kalwas, J. Winiarski, Archipelag islam, s. 176-177; Andrew, A. Jansen, Prześladowani za wiarę: dramatyczne historie chrześcijan nawróconych $z$ islamu, przeł. M. Wilk-Dziuba, Warszawa 2011, s. 323.

110 M. Yousafzai, Lamb C., To ja, Malala: historia pakistańskiej dziewczyny, która $z$ narażeniem życia walczy o prawa kobiet $i$ ich dostęp do edukacji, przeł. M. Moltzan-Małkowska, Warszawa 2014, s. 91-254.

111 G. Mortenson, D. O. Relin, Trzy filiżanki herbaty: opowieść o człowieku, który budując szkoły, dba o pokój na świecie, przeł. A. Lakatos. Katowice 2010, s. 172-174, 191198, 215-222. 
Próbując ocenić potencjalny wpływ edukacyjny zaprezentowanych powyżej pamiętników, trzeba pamiętać, że utwory biograficzne są o wiele chętniej czytane niż opracowania naukowe. Zatem bardziej jest prawdopodobne, że z tego typu źródła czytelnik zdobędzie wiedzę i wyrobi sobie na jego podstawie opinię o świecie islamu. Na rynku wydawniczym oferuje się mnóstwo literatury biograficznej o tematyce muzułmańskiej i - jak się wydaje - dopiero skorzystanie z kilku pozycji pozwoli na szersze spojrzenie na problem oraz wybrniecie ze stereotypu muzułmanina - potwora i terrorysty, oraz z równie nieadekwatnej zbitki „islam - religia pokoju”.

Warto podkreślić, że islam nie jest monolitem, a społeczeństwa muzułmańskie - poza różnicami wynikającym z lokalnych i ekonomicznych odrębności - w różnym stopniu realizują ideały religijne i odmiennie odpowiadają na wymogi współczesności, na co wskazują m.in. przytoczone powyżej pamiętniki. Można zatem dyskutować, czy kreślony w nich wizerunek jest reprezentatywny dla islamu jako całości czy nie, natomiast trudno zakwestionować prawdę doświadczeń poszczególnych ludzi.

Zaprezentowane powyżej obrazy świata islamu, które wyłaniają się z pamiętników, pokazują dwie jego główne odsłony: społeczność owładniętą przemocą motywowaną w sposób religijno-kulturowy oraz pokaźną grupę osób, zaangażowanych w walkę z ową przemocą, pragnących przemienić przemocową rzeczywistość. Który z tych światów zwycięży - trudno powiedzieć. Jednak jedno jest pewne: to, co się dzieje w środowiskach islamskich niewątpliwie będzie miało wpływ na nasze życie i przyszłość Europy.

Streszczenie: Artykuł przedstawia panoramę utworów biograficznych, kreślących obrazy życia w społecznościach muzułmańskich. Opowieści były budowane przez autobiografów wokół kilku zasadniczych tematów: konfliktów w małżeństwach mieszanych, doświadczeń specyficznej przemocy w rodzinie muzułmańskiej, prześladowań innowierców, terroru w dominiach pod panowaniem m.in. IsIs, Boko Haram, współczesnych zagrożeń terroryzmem i fanatyzmem islamskim. Ponadto dużą grupę pamiętników tworzą te, których głównym tematem jest reforma religii oraz konwersje z islamu na chrześcijaństwo. Wizerunek świata islamu, który wyłania się z pamiętników, to rzeczywistość, w której podstawowym problemem jest przemoc motywowana w sposób religijno-kulturowy. Doświadczenie przemocy lub sprzeciw wobec niej jest zazwyczaj główną osią narracji pamiętnikarskich. Autorzy biografii wskazują przede wszystkim na szariat - prawo religijne islamu jako główne źródło zachowań przemocowych.

Słowa kluczowe: islam, szariat, biografie, religia, kultura, edukacja. 


\section{Bibliografia}

Źródła:

Abed z Karabasz, Seyfo - ludobójstwo, o którym nie wolno mówić. Dziennik seminarzysty o ludobójstwie Ormian i Asyryjczyków w roku 1895 i w latach I wojny światowej, Poznań 2015.

Ali N., Dziesięcioletnia rozwódka, przeł. E. Wolańska, Warszawa 2009.

Al-Maghribi R., Czy Koran jest słowem Bożym? Świadectwo nawrócenia muzułmanina, przeł. S. Bednarowicz, Poznań 2011.

Al-Nahi D., Oddaj mi dzieci: dramatyczna opowieść o determinacji matki walczącej o odzyskanie porwanych dzieci, przeł. J. Pierzchała, Warszawa 2006.

Al-Nahi D., Bohaterka pustyni, przeł. A. Radkiewicz, Warszawa 2004.

Al-Samawi M., Polowanie na lisy. Prawdziwa historia uciekiniera z Jemenu, przeł. M. Słysz, Warszawa 2019.

Andrew, Janssen A., Prześladowani za wiarę: dramatyczne historie chrześcijan nawróconych $z$ islamu, przeł. M. Wilk-Dziuba, Warszawa 2011.

Apfeld N., Widziałam, jak zamordowano moją siostrę, przeł. A. Zaniewska, Ożarów Mazowiecki 2015.

Assiatou, Kaci M., Uprowadzona przez Boko Haram, przeł. K. Szeżyńska-Maćkowiak, Warszawa 2018.

Barakzai J., Pod burka, przeł. H. Abramowicz, Warszawa 2011.

Bibi A., Tollet A. I., Bluźnierstwo, przeł. P. Bachtin, Warszawa 2012.

Bin Ladin C., Rozdarty czarczaf: moje życie w Arabii Saudyjskiej, Katowice 2004.

Brahimi A., W niewoli algierskiego prawa, Wrocław 1999.

Dalen M. van, Kalifat albo śmierć, przeł. K. Markiewicz, Poznań 2017.

Darwish N., Okrucieństwo w majestacie prawa. Prześladowanie kobiet w świecie islamu, przeł. L. Bigaj, Warszawa 2011.

Dirie W., Miller C., Kwiat pustyni, przeł. M. Wrześniewski, Warszawa 1999.

Durrani T., Mój pan i władca, współpraca M. M. i W. Hoffer, przeł. L. Simbierowicz, Warszawa 2012.

Dżinan, Oberle T., Niewolnica ISIS, współpraca Thierry Oberlé, przeł. N. Jaskula, Gliwice 2016.

Erelle A., Dżihadystka: relacja z wnętrza komórki rekrutacyjnej Państwa Islamskiego, przeł. M. Chojnacki, Katowice 2015.

Esther G., Sangster T., Rozdarta zasłona, przeł. J. Piotrowski, Warszawa 2014.

Fadelle J., Bez względu na cenę, przeł. M. Cofta, Poznań 2011.

Falaise I., Mój mąż potwór, przeł. A. Sauvignon, Warszawa 2016.

Gabriel M. A., Jezus i Mahomet: głębokie różnice i zaskakujące podobieństwa, przeł. B. Grysa, Poznań 2013.

Gerber D., Pozostały mi tylko łzy i modlitwa, przeł. K. Markiewicz, Poznań 2013. 
Goode R., Nikt ich nie zamknie: niezwykłe, prawdziwe historie Bożego działania w świecie islamu, przeł. D. Piotrowska, Warszawa 2011.

Hamid N., Dzieci szariatu: losy tych, o których upomniał się islam, Pelplin 2018.

Hamid N., Gorzka pomarańcza: ucieczka ze świata islamu: historia Polki, żony muzutmanina, Pelplin 2016.

Hamid N., Jarzmo przeszłości, Pelplin 2017.

Mosallai Bell B. M., Harris S., Perska księżniczka. Amerykanka z urodzenia, Iranka z miłości - prawdziwa historia jej życia, przeł. A. Cioch, Warszawa 1999.

Hirsi Ali A., Heretyczka, przeł. J. Żuławnik, Warszawa 2016.

Hirsi Ali A., Niewierna. Grozili mi, że będę następna, przeł. J. Pierzchała, Warszawa 2009. Hirsi Ali A., Nomadka. Zbuntowana przeciw islamowi, przeł. E. Krawczyk, Warszaw 2013. Husnain A., Chester J., Niewierny, przeł. A. Czwojdrak, Kraków 2016.

Hussaini S., Żyję dzięki wam, przeł. M. Żbikowska, Warszawa 2004.

James S., Sabatina, Warszawa 2003.

Jusuf M. H., Brackin R., Syn Hamasu, przeł. A. Kurzępa, Wrocław 2014.

Kasiki S., Guéna P., Piekło IsIs, przeł. T. Markowski, Warszawa 2016.

Kaźmierczak-Ali S., Wybuchowe związki: małżeństwo z Pakistańczykiem, Gdynia 2019.

Khalaf F., Dziewczyna, która pokonała IsIs. Moja historia, przeł. B. Tarnas, Warszawa 2016.

Khan A., Islamski bękart, przeł. J. Skowroński, Warszawa 2013.

Larson J.A., Woziłam arabskie księżniczki: opowieść szoferki o najbogatszych księżniczkach świata (oraz ich służących, nianiach i jednym królewskim fryzjerze), przeł.

D. Malina, Kraków 2014.

Lauren J., Moje życie w haremie, przeł. E. Piotrowska, Warszawa 2012.

Leila, Zmuszona do małżeństwa, przeł. B. Walicka, Warszawa 2018.

Lemmon G. T., Wojna Ashley, przeł. J. Ochab, Warszawa 2017.

Mahmoody B., Tylko razem z córka, przeł. M. Kwiatkowska, Warszawa 1992.

Mamoń M., Wojna braci. Bojownicy, dżihadyści, kidnaperzy, rozm. A. Drożdżak, Kraków 2017.

Manji I., Kłopot z islamem, przeł. M. Świerkocki, Warszawa 2005.

Margielewski M., Jak podrywają szejkowie, Warszawa 2019.

Morgan V., Zakazana miłość, przeł. M. Leszczyk, Warszawa 2011.

Mortenson G., Relin D. O., Trzy filiżanki herbaty: opowieść o człowieku, który budując szkoły, dba o pokój na świecie, przeł. A. Lakatos. Katowice 2010.

Muhsen Z., Sprzedane przez ojca, przeł. M. Rostworowska, Warszawa 2013.

Muller R., Człowiek z Gadary, przeł. D. Piotrowska, Warszawa 2011.

Murat N., Krajeski J., Ostatnia dziewczyna: o mojej niewoli i walce z Państwem Islamskim, przeł. M. Koziej, Warszawa 2018.

N. N., Polowałam na terrorystów, przeł. M. Szubert, Warszawa 2004.

Nash E., Pustynny snajper, przeł. R. Kot, Poznań 2019.

Nazer M., D. Lewis, Niewolnica, przeł. H. Szajowska, Warszawa 2004. 
Onal A., Honor albo śmierć. Niewierne będa ginąć, przeł. J. Żuławnik, Warszawa 2009.

Owen M., Niełatwy dzień, autobiografia komandosa Navy SEAL: pierwsza i jedyna relacja komandosa sił specjalnych Navy SEAL, które doprowadziły do śmierci Osamy Bin Ladena, przeł. Ł. Małecki, Kraków 2013.

Pascarl J., Kiedyś byłam księżną, przeł. E. Szyler, Warszawa 2012.

Qureshi N., Szukając Allaha znalazłem Jezusa. Droga gorliwego muzułmanina do Chrystusa, przedm. L. Strobel, przeł. A. Dominowska, Ustroń 2015.

Rostampour M., Amirizadeh M., Więźniowie Iranu: prawdziwa historia dwóch chrześcijanek, przeł. M. Rucki, Poznań 2013.

Saada T., Merril D., Byłem człowiekiem Arafata, przeł. M. Rucki, Poznań 2013.

Saada T., Merril D., Umysł terrorysty: były snajper Arafata ujawnia motywy islamskich ekstremistów i podpowiada, jak przeciwdziałać terroryzmowi, przeł. A. Czwojdrak, Wrocław 2017.

Saillo O., Księżyc we łzach, przeł. B. Ostrowska, Warszawa 2010.

Samir, Zapiski z Rakki. Ucieczka z Państwa Islamskiego, przeł. M. Romanek, Kraków 2017.

Sasson J., Księżniczka, przeł. I. Chodorowska, Warszawa 2004.

Sasson J., Bin Laden N., Bin Laden O., Musiałam odejść: wspomnienia żony i syna Osamy Bin Ladena, przeł. A. Sokołowska-Ostapko, Kraków 2012.

Seierstad A., Księgarz z Kabulu, przeł. A. Marciniakówna, Warszawa 2005.

Shariff S., Pohańbione, przeł. J. Józefowicz-Pacuła, Warszawa 2011.

Shariff S., Za zasłona strachu, przeł. J. Józefowicz-Pacuła, Warszawa 2011.

Shirin, Cavelius A., Kizilhan J., Pozostanę córką światła. Moja ucieczka z rąk terrorystów, przeł. M. Jatowska, Warszawa 2017.

Souad, Spalona żywcem, współpraca M. T. Cuny, przeł. M. Rostworowska, Warszawa 2004.

Storm M., Cruickshank P., Lister T., Agent Storm we wnętrzu Al-Kaidy i cIA, Wołowiec 2013.

Suc M., Żony dżihadystów, przeł. K. Szeżyńska-Maćkowiak, Warszawa 2017.

Sundberg A., Huor J., Żona terrorysty. Szesnaście lat życia wśród dżihadystów, przeł. I. Sawicka, Warszawa 2017.

Tiouli T., Honor kobiety. Ofiara gwałtu uwięziona w Dubaju, przeł. M. Kowalska, Warszawa 2007.

Trevane J., Fatwa. Życie w nieustannym zagrożeniu, przeł. H. Pawlikowska-Gannon, Fr̄ydek-Mistek 2006.

Warraq Ibn, Dlaczego nie jestem muzułmaninem, przeł. K. M. Wielgat, G. Kuśmierek, Warszawa 2013.

Yousafzai M., Lamb C., To ja, Malala: historia pakistańskiej dziewczyny, która z narażeniem życia walczy o prawa kobiet $i$ ich dostęp do edukacji, przeł. M. Moltzan-Małkowska, Warszawa 2014.

Zoja, Wszystkie jesteście niewierne. Piekło kobiet w Afganistanie, Warszawa 2009. 


\section{Literatura przedmiotu}

Białobrzeski T., Małżeństwo katolika z muzułmaninem w świetle Instrukcji Konferencji Episkopatu Hiszpanii z 2008 roku, „Ius Matrimoniale”, 2011, nr 16 (22), s. 117-141.

Dajnowicz-Piesiecka D., Porwania rodzicielskie w świetle polskiego orzecznictwa karnego w ujęciu prawnym i kryminologicznym (na podstawie badań aktowych), „Dziecko Krzywdzone. Teoria, badania, praktyka”, 15 (2016) nr 4, s. 65-86.

Danecki J., Podstawowe wiadomości o islamie, Warszawa 2007.

Descent-based slavery, https://www.antislavery.org/slavery-today/descent-based-slavery/, dostęp: 01.06.2019.

Dziekan M., Dzieje kultury arabskiej, Warszawa 2008.

Female genital mutilation (FGM) data, https://data.unicef.org/resources/dataset/fgm/, dostęp: 06.06.2019.

Gutkowska A., Kulturowa przemoc ze względu na płeć. Przypadek zabójstw honorowych, „Archiwum Kryminologii”, 35 (2013) s. 137-160.

Is there any saheeh hadeeth about the circumcision of females?, https://islamqainfo/ en/answers/82859/is-there-any-saheeh-hadeeth-about-the-circumcision-of-females, dostęp: 06.06.2019.

Islam. Sto pytań, odpowiada Samir Khalil Samir, Warszawa 2004.

Kalwas P. I., Winiarski J., Archipelag islam. Czas Koranu, czas zmiany: rozmowy bez cenzury, Nysa 2018.

Khidayer E., Arabski świat, przeł. A. Mickiewicz-Janiszewska, Warszawa 2012.

KościelniakK., Sunna, hadisy, tradycjoniści, Kraków 2006.

Kościelniak K., Tematyczna konkordancja do Koranu, Kraków 2006.

Laurent S., Kalifat terroru. Kulisy działania Państwa Islamskiego, przeł. E. Kaniowska, Warszawa 2015.

Medical benefits of female circumcision, https://islamqa.info/en/answers/45528/medical-benefits-of-female-circumcision, dostęp: 01.06.2019.

Oliwa D., W cieniu niewolnictwa - konfrontacja prawa z rzeczywistością w systemie państwa i społeczeństwa Mauretanii, w: Prawa człowieka w kulturze pótnocnej Afryki, Bliskiego Wschodu i Dalekiego Wschodu, red. K. Kościelniak, Kraków 2008, s. 69-87.

Orzechowski M., Mój sąsiad islamista, Warszawa 2016.

Perpetual Minors. Human Rights Abuses Stemming from Male Guardianship and Sex Segregation in Saudi Arabia, New York 2008.

Prochwicz-Studnicka B., M. Teperska-Klasińska, Cywilizacja islamu. Wybrane struktury, „The Polish Journal of the Arts and Culture”, 3 (2012) s. 153-202.

Prześladowania chrześcijan na świecie, https://www.opendoors.pl/przesladowania-chrzescijan/przesladowania-mapa, dostęp: 15.05.2019.

Sadowa K., Ghayra i namus a zjawisko zbrodni "honorowych" w społecznościach muzutmańskich - zarys problemu, „Wrocławskie Studia Erazmiańskie”, 9 (2015) s. 377-392. 
Sadowa K., Przewinienia hudūd w klasycznym prawie karnym muzułmańskim - zarys tematyki, „Acta Erasmiana”, 15 (2017) s. 36-37.

Sadowa K., Zbrodnie „honorowe” problemem współczesnej Europy? Zarys tematyki, „Wrocławskie Studia Erazmiańskie”, 7 (2013) s. 217-219.

Sadowa K., Zjawisko tzw. zbrodni honorowych $w$ Europie a koncepcja czystości $w$ islamie - zarys problematyki, „Colloquium Wydziału Nauk Humanistycznych i Społecznych AMW", 3 (2015) s. 181-198.

Sadowski M., Islam. Religia i prawo, Warszawa 2017.

Sitek M., Opieka i kuratela dotycząca osoby ubezwłasnowolnionej w prawie polskim, „Internetowy Przegląd Prawniczy TBSP UJ”, 2013, nr 1 (11), s. 77-91.

Stopikowska M., „Przeżyłam piekło” - doświadczenia kobiet $w$ świetle pamiętników muzułmanek i żon muzułmanów - między stereotypem a rzeczywistością, w: Etykieta czy drogowskaz? Rola stereotypów w przestrzeniach edukacyjnej różnorodności, red. M. Łojko, M. Grochalska, Olsztyn 2013, s. 203-220.

Stopikowska M., Koran pod pachą emigranta - potencjalne zagrożenie?, w: Migracja: szansa czy zagrożenie?, red. J. Zimny, Stalowa Wola 2015, s. 173-201.

Stopikowska M., Matżeństwa polsko-arabskie: specyfika i zagrożenia, w: Nauki o rodzinie $w$ służbie rodziny, red. J. Stala, Kraków 2014, s. 541-559.

Stopikowska M., Muzułmanie i ich emigracja na „Zachód”, w: Migracja: szansa czy zagrożenie?, red. J. Zimny, Stalowa Wola 2015, s. 25-50.

Stopikowska M., Różnice doktrynalne: islam i chrześcijaństwo - wybrane aspekty, (mps.).

Wąsik D., Bluźnierstwo w wybranych kulturach prawnych, „Studia Iuridica Toruniensia", 15 (2014) s. 216-220.

Zyzik M., Małżeństwo w prawie muzułmańskim, Warszawa 2003. 